\title{
ADSORPTION REMOVAL OF ANTHOCYANINS FROM RED CABBAGE EXTRACTS BY BENTONITE: STATISTICAL ANALYSIS OF MAIN AND INTERACTION EFFECTS
}

\author{
Odessa I.I. Mechnikov National University \\ 2 Dvoryanskaya Str., Odessa, 65082, Ukraine, E-mail: soldatkina@onu.edu.ua
}

In recent years, anthocyanins are widely used in food industry as natural dyes and in medicine as compounds with high antioxidant activity. In connection with this, examination of adsorption removal of anthocyanins from extracts of cheap plants containing a lot of these compounds as well as of main and interaction effects which influent on adsorption of anthocyanins is important. In this paper, experiments were conducted according to full factorial experimental design to identify the main and interaction effects of factors and their influence on the removal efficiency of anthocyanins from red cabbage aqueous extracts by bentonite. The factors were investigated at two levels: contact time - 30 and 120 min, temperature - 293 and $323 \mathrm{~K}$, initial anthocyanin concentration 70 and $130 \mathrm{mg} / \mathrm{L}$, and adsorbent mass -10 and $25 \mathrm{~g} / \mathrm{L}$. The total number of 16 experiments was performed and each experiment was repeated thrice to evaluate an experimental error. Main and interaction effects were analysed using of variance (ANOVA), F-test and P-values to define most important process variables affecting the anthocyanin adsorption. A mathematical model that considers the significant main and interaction effects was suggested. The variance analysis and the statistic data showed that the model was adequate and had high coefficient of determination $\left(R^{2}=0.9954\right)$. The mathematical model obtained allows prediction of the removal of anthocyanins from red cabbage aqueous extracts with bentonite. We have found that the contact time and adsorbent mass have the positive effect, but the initial concentration of anthocyanins and temperature as well as two-way interaction "contact time-temperature", three-way interactions "contact time-initial anthocyanin concentration-adsorbent mass" and "temperature-initial concentration of anthocyanins-adsorbent mass" have the negative effect on the removal of anthocyanins from red cabbage extracts by bentonite. The results indicated that higher removal efficiency of anthocynians from red cabbage aqueous extracts was $95 \%$ at $120 \mathrm{~min}, 293 \mathrm{~K}$, initial anthocyanin concentration $70 \mathrm{mg} / \mathrm{L}$, and adsorbent mass $25 \mathrm{~g} / \mathrm{L}$.

Keywords: adsorption, anthocyanins, red cabbage, bentonite, statistical analysis, main effects, interaction effects

\section{INTRODUCTION}

In recent years, numerous studies proved that such natural dyes as anthocyanins could be an alternative to carcinogenic synthetic dyes in the food industry [1]. On the other hand, natural dyes are also effective in medicine for the prevention and treatment of cardiovascular and visual diseases, diabetes, cancer and others because they have high antioxidant activity [2]. Therefore, in many countries intensive studies are conducted with the purpose to choose cheap plant materials containing a lot of anthocyanins and to optimize effective methods of removal and purification of anthocyanins from them.

Frequently, the way to obtain anthocyanins is an operation using a static method of extraction where the raw material, rich in anthocyanins, is macerated in contact with the solvent. At the end of the extraction process, the extract is filtered and purified. The most promising method in this field is adsorption which allows us to concentrate and to purify anthocyanins from their extracts [3-7] and it is also relatively simple in design and operation [7].

In this connection, red cabbage is a widespread agro-industrial plant in many European countries and could be a cheap source of anthocyanins. Undoubtedly, the choice of red cabbage is cost-effective, because its cultivation and harvest are inexpensive and the storage is not difficult. After all, acylated anthocyanins found in red cabbage are biologically more active than many other compounds in this group [8]. According to the studies $[9,10]$, aqueous 
and alcohol extracts of red cabbage can be used for coloration of soft drinks and ice-cream. But the aim of these studies was to investigate only anthocyanin stability in their extracts under the effect of different factors.

Red cabbage is also a rich source of sulfurcontaining glucosinolates known as thiocyanates, isothiocyanates and others. If we store the extracts of red cabbage, the sulfur-containing substances are destroyed and form light sulfur compounds (dimethyl disulfide and dimethyl trisulfide) producing a disagreeable smell described as "stuffy odour" [11]. On the one hand, the study [12] showed a low adsorption capacity of clay minerals to glucosinolates, because the anionic glucosinolates repelled from the negatively charged clay surface. On the other hand, cationic anthocyanins in acidic region of $\mathrm{pH}$ can be adsorbed on the negatively charged clay surface. Therefore, adsorption by clay minerals can be used as a relatively simple method of removal of anthocyanins from extracts which contain undesirable components.

Nowadays, a full factorial design is a powerful technique for characterisation, optimisation and modelling of the adsorption process. Unfortunately, information about the influence of different factors and their interaction effects on adsorption removal of anthocyanins from red cabbage extracts by a cheap adsorbent as bentonite is not available. In the present work we used full factorial design $2^{4}$ in order to examine individual and interactive effects of the four main independent parameters, namely contact time $(\tau)$, temperature $(T)$, initial anthocyanin concentration $(C)$, adsorbent mass $(m)$ on the anthocyanin removal efficiency from red cabbage extracts by bentonite.

\section{MATERIALS AND METHODS}

Plant material and chemicals. Red cabbage (Brassica oleracea L.) was harvested in Odessa region (Ukraine) in 2016. The cabbage heads were washed, dried, and stored in polyethylene bags at $277 \mathrm{~K}$ until the time of processing. Only the leaves of red cabbage were used in the experiments.

Chemical reagents of analytical grade (hydrochloric acid, glacial acetic acid, sodium acetate (trihydrate), potassium chloride) were purchased from Cherkassy State Chemical Plant (Ukraine).
Preparation of the red cabbage extract. The extract of red cabbage was obtained from its shredded leaves by maceration with $0.1 \mathrm{M} \mathrm{HCl}$ (as $1: 2=\mathrm{w}: \mathrm{v}$ ) during $24 \mathrm{~h}$ at $293 \mathrm{~K}$ in the dark. Then the red cabbage extract was filtered and centrifuged. The extract was stored at $277 \mathrm{~K}$.

Some characteristics of the red cabbage extract such as initial anthocyanin concentration $(C)$, pH-value, density $(\rho)$, viscosity $(\eta)$, and Briggs coefficient $\left({ }^{\circ} B_{\mathrm{x}}\right)$ are shown in Table 1 .

Table 1. Characteristics of the red cabbage extract at $293 \mathrm{~K}$

\begin{tabular}{cc}
\hline Properties & Value \\
\hline$C, \mathrm{mg} / \mathrm{g}$ & $130.0 \pm 6.5$ \\
$\mathrm{pH}$ & $1.60 \pm 0.02$ \\
$\rho, \mathrm{g} / \mathrm{cm}^{3}$ & $1.080 \pm 0.001$ \\
$\eta, \mathrm{mPa} \cdot \mathrm{s}$ & $5.39 \pm 0.02$ \\
${ }^{\circ} B_{\mathrm{x}}$ & $43.0 \pm 0.1$ \\
\hline
\end{tabular}

The total anthocyanin content in extract $(C)$ was determined by $\mathrm{pH}$-differential method [13] as mg cyanidin-3-glucoside per one litre of the extract using the following equation:

$C=\frac{\left[\left(A_{525}-A_{700}\right)_{p H=1.0}-\left(A_{510}-A_{700}\right)_{p H=4.5}\right] \cdot M \cdot D F \cdot 1000}{l \cdot \varepsilon}$,

where $A_{525}$ and $A_{700}$ are the absorbances of an extract at $\mathrm{pH} 1.0$ and at $\mathrm{pH} 4.5 ; M$ is the molecular weight of cyanidin-3-glucoside (449.2); $D F$ is the dilution factor as a final volume per the initial volume; $l$ is the path length (cm); $\varepsilon$ is the molar extinction coefficient (26 $300 \mathrm{~L} /(\mathrm{mol} \cdot \mathrm{cm})$ of cyanidin-3-glucoside); 1000 is a conversion factor from $\mathrm{g}$ to $\mathrm{mg}$. The absorbance of each extract was measured at 525 and $700 \mathrm{~nm}$ using an UV-VIS spectrophotometer (SF-56, Spectral, Russia).

The measurement of $\mathrm{pH}$ of anthocyanin extract was carried out using a $\mathrm{pH}$ meter (Universal ionomer EV-74, BLR). Briggs coefficient was calculated using refractive index which was measured with a refractometer (Abbe Refractometer RL-1, Poland). The determination of density of anthocyanin extract was carried out by a picnometer. The kinematic viscosity of the extract was measured using a capillary Ubbelohde viscometer.

Adsorbent preparation. Bentonite from Dashukovsky deposit in Ukraine (TU U14.200223941-006:2010) was used as cheap and 
available adsorbent. It refers to alkaline earth silicate and has the following chemical composition (\%): $\quad \mathrm{SiO}_{2}-49.6 ; \quad \mathrm{Al}_{2} \mathrm{O}_{3}-13.5$; $\mathrm{Fe}_{2} \mathrm{O}_{3}-7.2$ [14].

Before adsorption studies, bentonite was pounded in a porcelain mortar and washed with distilled water at $293 \mathrm{~K}$ to remove impurities and then dried at $368 \mathrm{~K}$ for $24 \mathrm{~h}$ to remove moisture.

Adsorption studies. All adsorption experiments were carried out in static conditions, shaking mixtures of anthocyanin extracts of red cabbage with bentonite at agitation speed $150 \mathrm{rpm}$. After adsorption these mixtures were filtered out and concentrations of anthocyanins were determined by pH-differential method. The anthocyanin removal efficiency $(\alpha)$ was defined using the equation:

$\alpha=\frac{C_{o}-C}{C_{o}} \cdot 100 \%$,

where $C_{o}$ and $C$ are the concentrations of anthocyanins in extracts before and after adsorption (mg/L).

Full factorial experimental design and statistical analysis. The main steps of the full factorial experimental design are the determination of response variables, factors and factor levels; choice of the experimental design; execution of an experiment; statistical analysis of the experimental data; examination of the main factors and their interactions, obtaining a mathematical model of the process; and checking the adequacy of the model.

It is well known that the adsorption capacity of adsorbents for anthocyanin removal is affected by several factors, for example, such as $\mathrm{pH}$, temperature, initial concentration of anthocyanins, adsorbent mass, contact time and others. On the one hand, the classical experiment allows us to study the effect of only one factor which is assessed by varying its value providing that all other factors are kept constant. So, the classical experiment cannot capture interactions between different factors [15]. On the other hand, by factorial planning of the experiments it was possible to investigate the effects of all the variables simultaneously using a minimum number of experiments [16].

In this study, the full factorial experimental design $2^{4}$ was selected to evaluate the main and interaction effects of the factors on anthocyanin removal. The independent variables were contact time, temperature, initial anthocyanin concentration, and adsorbent mass. Each variable was investigated at two levels: high and low. The levels of the factors were selected according to our preliminary experiments. Factors, their abbreviations and levels are shown in Table 2. The anthocyanin removal efficiency was chosen as dependent response variable.

Table 2. Selected values of the variables investigated in the factorial experiment

\begin{tabular}{lccc}
\hline \multicolumn{1}{c}{ Factor } & Abbreviation & Low level (-1) & High level (+1) \\
\hline Time, min & $\tau$ & 30 & 120 \\
Temperature, K & $T$ & 293 & 323 \\
Initial anthocyanin concentration, & & & 130 \\
mg/L & $C$ & 70 & 25 \\
Adsorbent mass, g/L & $m$ & 10 & \\
\hline
\end{tabular}

\section{RESULTS AND DISCUSSION}

All experiments were chosen randomly to prevent partiality of researchers and to avoid systematic errors. The factorial matrix and the results of the removal efficiency of anthocyanins from red cabbage extracts by bentonite are shown in Table 3 . The total number of 16 experiments was performed and each experiment was repeated thrice.

The obtained results were analysed using MINITAB 16 statistical software to evaluate the effects as well as the statistical parameters, the statistical plots (Pareto, main effects, and interaction plots). The interactions between independent factors were determined with the analysis of variance (ANOVA) and the main effects of anthocyanin adsorption were identified based on the $P$-value with $>95 \%$ of confidence level. The effects, regression coefficients, standard errors, the Student's test ( $t$-test), and $P$-values are shown in Table 4.

ANOVA. The determination of the significant factors affecting the removal efficiency of red cabbage anthocyanins by bentonite was carried out 
by performing ANOVA (Table 5 ). Since for our studies tabulated $F$-test $(0.05 ; 2 ; 32)=3.63$, all the effects with F-test higher than 3.63 are statistically significant, besides they must have a $P$-value less than 0.05 . The results from Table 5 confirm that contact time, temperature, initial concentration of anthocyanians, and adsorbent mass show significant effect on the removal efficiency of anthocyanins from red cabbage extracts by bentonite. Interaction effects are significant with only two-way interaction "contact timetemperature", three-way interactions "contact timeinitial anthocyanin concentration-adsorbent mass" and "temperature-initial anthocyanin concentration-adsorbent mass”.

Table 3. Adsorption removal efficiency of anthocyanins from red cabbage extracts by bentonite

\begin{tabular}{|c|c|c|c|c|c|c|c|}
\hline \multirow{2}{*}{ Run } & \multirow{2}{*}{$\tau$} & \multirow{2}{*}{$T$} & \multirow{2}{*}{$C$} & \multirow{2}{*}{$m$} & \multicolumn{2}{|c|}{ Removal efficiency, \% } & \multirow{2}{*}{ Residual } \\
\hline & & & & & Average & Predicted & \\
\hline 1 & -1 & -1 & -1 & -1 & 72.2 & 72.4 & 0.2 \\
\hline 2 & +1 & -1 & -1 & -1 & 87.2 & 88.4 & 1.2 \\
\hline 3 & -1 & +1 & -1 & -1 & 75.0 & 75.3 & 0.3 \\
\hline 4 & +1 & +1 & -1 & -1 & 76.7 & 75.5 & -1.2 \\
\hline 5 & -1 & -1 & +1 & -1 & 55.0 & 55.6 & 0.7 \\
\hline 6 & +1 & -1 & +1 & -1 & 78.9 & 78.5 & -0.5 \\
\hline 7 & -1 & +1 & +1 & -1 & 63.6 & 62.8 & -0.8 \\
\hline 8 & +1 & +1 & +1 & -1 & 69.9 & 69.8 & 0.0 \\
\hline 9 & -1 & -1 & -1 & +1 & 73.3 & 72.5 & -0.7 \\
\hline 10 & +1 & -1 & -1 & +1 & 95.5 & 95.4 & -0.1 \\
\hline 11 & -1 & +1 & -1 & +1 & 79.5 & 79.8 & 0.3 \\
\hline 12 & +1 & +1 & -1 & +1 & 86.9 & 86.8 & -0.1 \\
\hline 13 & -1 & -1 & +1 & +1 & 67.1 & 66.9 & -0.2 \\
\hline 14 & +1 & -1 & +1 & +1 & 83.6 & 83.0 & -0.7 \\
\hline 15 & -1 & +1 & +1 & +1 & 69.5 & 69.8 & 0.2 \\
\hline 16 & +1 & +1 & +1 & +1 & 68.8 & 70.0 & 1.2 \\
\hline
\end{tabular}

Table 4. Statistical parameters for $2^{4}$ designs

\begin{tabular}{|c|c|c|c|c|c|c|}
\hline Term & Effects & Coefficients & Standard error & $t$-test & $P$-value & Status \\
\hline Constant & & 75.17 & 0.3231 & 232.68 & 0.000 & \\
\hline$\tau$ & 11.54 & 5.77 & 0.3231 & 17.85 & 0.000 & Significant \\
\hline$T$ & -2.88 & -1.44 & 0.3231 & -4.45 & 0.000 & Significant \\
\hline C & -11.22 & -5.61 & 0.3231 & -17.36 & 0.000 & Significant \\
\hline$m$ & 5.72 & 2.86 & 0.3231 & 8.86 & 0.000 & Significant \\
\hline$\tau \times T$ & -7.88 & -3.94 & 0.3231 & -12.19 & 0.000 & Significant \\
\hline$T \times C$ & -0.32 & -0.16 & 0.3231 & -0.50 & 0.348 & \\
\hline$\tau \times C$ & -0.06 & -0.03 & 0.3231 & -0.08 & 0.395 & \\
\hline$\tau \times m$ & -0.20 & -0.10 & 0.3231 & -0.30 & 0.378 & \\
\hline$T \times m$ & -0.84 & -0.42 & 0.3231 & -1.29 & 0.172 & \\
\hline$C \times m$ & -0.30 & -0.15 & 0.3231 & -0.45 & 0.356 & \\
\hline$\tau \times T \times C$ & -0.86 & -0.43 & 0.3231 & -1.33 & 0.163 & \\
\hline$\tau \times C \times m$ & -3.40 & -1.70 & 0.3231 & -5.28 & 0.000 & Significant \\
\hline$\tau \times T \times m$ & -0.12 & -0.06 & 0.3231 & -0.18 & 0.389 & \\
\hline $\mathrm{t} \times C \times m$ & -2.18 & -1.09 & 0.3231 & -3.38 & 0.003 & Significant \\
\hline$\tau \times T \times C \times m$ & 0.24 & 0.12 & 0.3231 & 0.36 & 0.370 & \\
\hline
\end{tabular}

Pareto chart. The results given above were verified by the Pareto chart (Fig. 1) where the vertical line with 2.04 value indicates the minimum statistically significant effect magnitude. It was calculated for the $95 \%$ confidence level and 32 freedom degrees. The values which exceed a reference line are significant ones. According to Fig. 1, the main factors $(\tau, C, T$, and $m$ ) and their two-way interaction "contact time-temperature", threeway interactions "contact time-initial anthocyanin concentration-adsorbent mass" and 
"temperature-initial anthocyanin concentrationadsorbent mass" are extended over the limits of the reference line and are significant at the level of 0.05 . The rest of their interactions have smaller effects and are statistically insignificant.

Main effects. Main effects of each control factor influencing removal of anthocyanins from red cabbage extracts are shown in Fig. 2. It can be seen that the contact time has more positive influence upon the removal efficiency of anthocyanins than the adsorbent mass. The increasing of the contact time and mass of the adsorbent contributes to the increase in the removal efficiency of anthocyanin. The initial anthocyanin concentration has a more negative influence upon the anthocyanin removal efficiency than the temperature. The increase of the initial anthocyanin concentration and temperature reduces the anthocyanin removal efficiency. The maximum removal efficiency of anthocyanins from red cabbage extracts takes place at the low initial concentration and temperature, high contact time and adsorbent mass.

Table 5. Analysis of variance

\begin{tabular}{|c|c|c|c|c|c|c|}
\hline Source & DF & SS & MS & $F$-test & $P$-value & Status \\
\hline$\tau$ & 2 & 1596.21 & 798.11 & 239.00 & 0.000 & Significant \\
\hline$T$ & 2 & 99.19 & 49.59 & 14.85 & 0.000 & Significant \\
\hline$C$ & 2 & 1509.76 & 754.88 & 226.05 & 0.000 & Significant \\
\hline$m$ & 2 & 393.31 & 196.65 & 58.89 & 0.000 & Significant \\
\hline$\tau \times T$ & 2 & 744.19 & 372.09 & 111.43 & 0.000 & Significant \\
\hline$T \times C$ & 2 & 0.03 & 0.02 & 0.00 & 0.348 & \\
\hline$\tau \times C$ & 2 & 1.27 & 0.63 & 0.19 & 0.395 & \\
\hline$\tau \times m$ & 2 & 0.44 & 0.22 & 0.07 & 0.378 & \\
\hline$T \times m$ & 2 & 8.33 & 4.17 & 1.25 & 0.172 & \\
\hline$C \times m$ & 2 & 1.02 & 0.51 & 0.15 & 0.356 & \\
\hline$\tau \times T \times C$ & 2 & 8.84 & 4.42 & 1.32 & 0.163 & \\
\hline$\tau \times C \times m$ & 2 & 139.40 & 69.70 & 20.87 & 0.000 & Significant \\
\hline$\tau \times T \times m$ & 2 & 0.16 & 0.08 & 0.02 & 0.389 & \\
\hline$T \times C \times m$ & 2 & 57.20 & 28.60 & 8.56 & 0.003 & Significant \\
\hline$\tau \times T \times C \times m$ & 2 & 0.65 & 0.33 & 0.10 & 0.370 & \\
\hline Error & 16 & 53.43 & 3.34 & & & \\
\hline Total & 47 & 4613.44 & & & & \\
\hline
\end{tabular}

DF: degrees of freedom; SS: sum of squares; MS: mean square

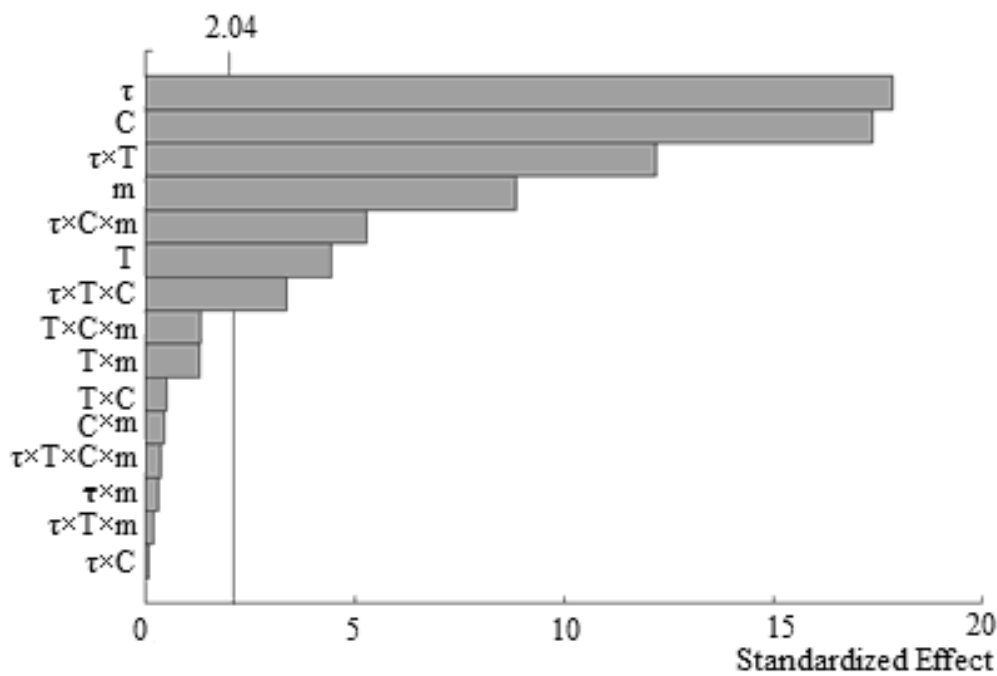

Fig. 1. Pareto chart of standardized effects on the removal efficiency of anthocyanins from red cabbage extracts 
Unfortunately, no information was published about the main effects of control factors on the removal efficiency of anthocyanins from red cabbage extracts. According to [17], for the full factorial experimental design $2^{3}$ the initial concentration of Neutral red dye has the most negative influence on the dye removal on sand with bentonite. Respectively, the contact time has a more positive influence upon the removal efficiency of anthocyanins than the adsorbent mass.

Interaction effects. The full factorial experimental design describes which control factor has a greater impact and how factors affect each other simultaneously [18]. The interactions between two different control factors and their effects on the removal efficiency of anthocyanins are shown in Fig. 3.
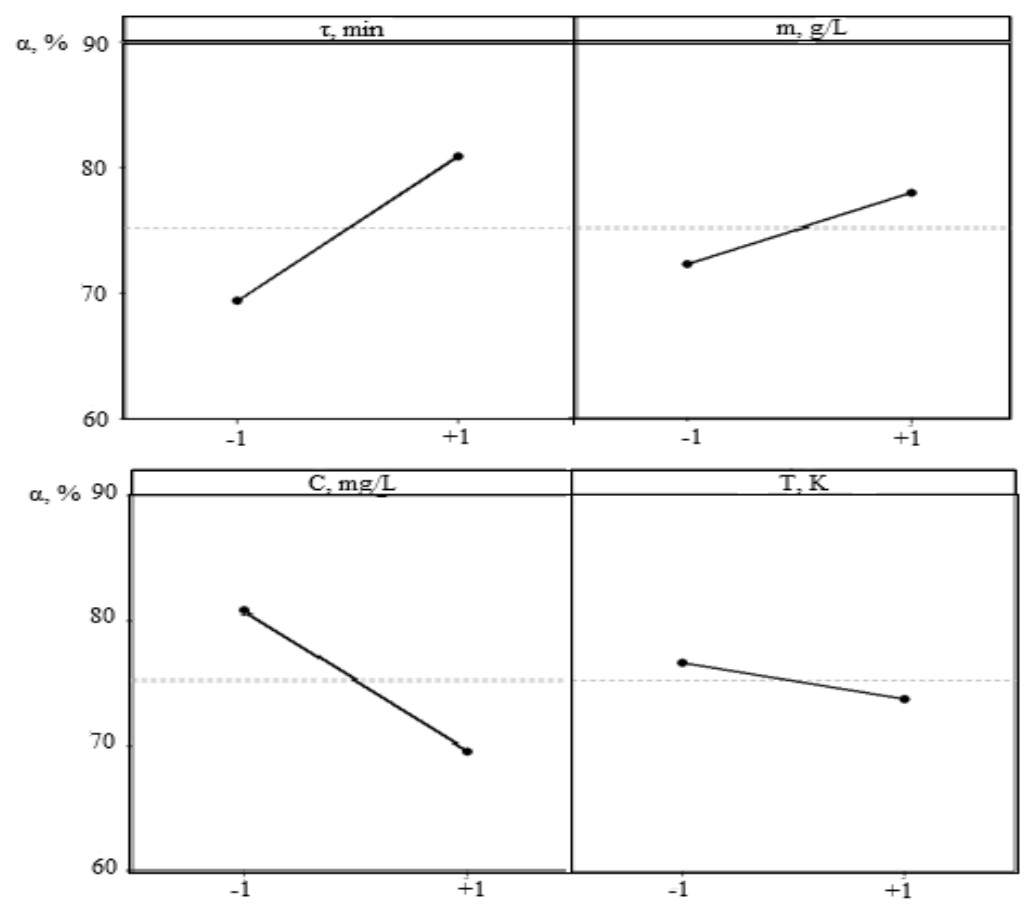

Fig. 2. The plot of the main effects for the removal efficiency of anthocyanins from red cabbage extracts by bentonite

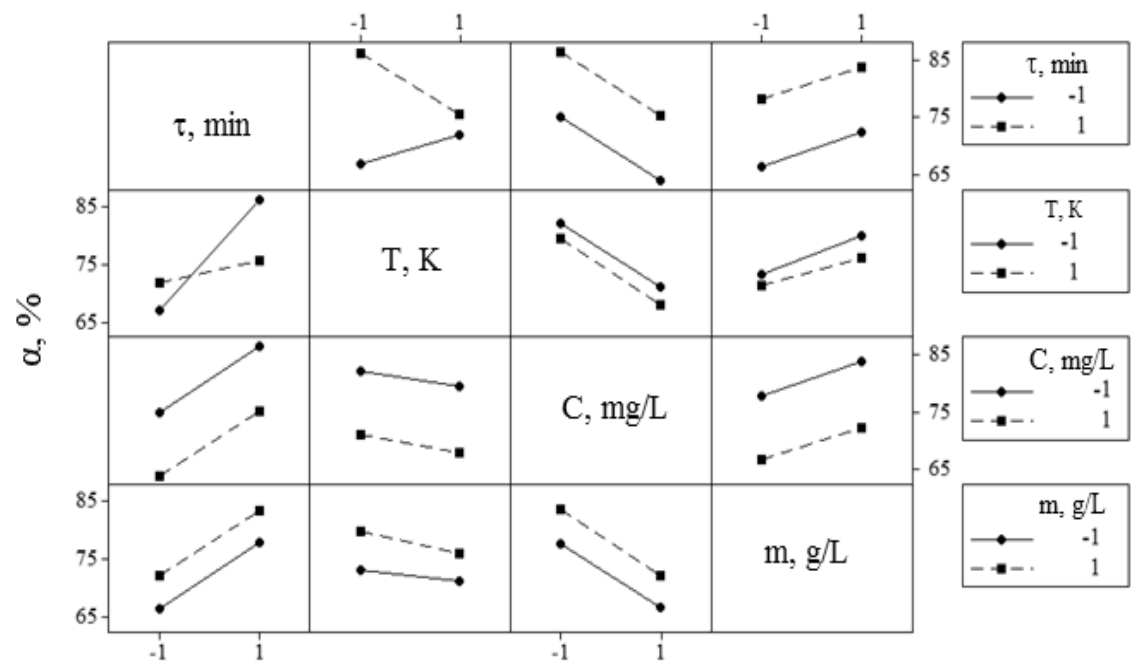

Fig. 3. Interaction effects for the removal efficiency of anthocyanins from red cabbage extracts by bentonite 
The two-way interactions among different control factors for the removal of red cabbage anthocyanins by bentonite are shown in Fig. 3. According to [19], the interactions between control factors are effective when the change in the response from low to high levels of a factor is dependent on the level of the second factor, viz. when the lines of the interaction effects do not run parallel.

As it is shown in Fig. 3, the lines of interaction effects such as the contact time and temperature are far from being parallel and the interaction between these factors is effective. That is, the high level effect of the contact time on the removal of anthocyanins from red cabbage extracts will be higher if the temperature is maintained at a low level. And vice versa, the high level effect of temperature on the removal of anthocyanins from red cabbage extracts will be higher if the contact time is kept at a low level.

Modelling of anthocyanin removal by bentonite. Taking into account the statistical treatment of our experimental data given above we obtained mathematical model for the removal efficiency of anthocyanins from red cabbage by bentonite according to the following first-order polynomial equation: $\alpha=75.17+5.77 \tau-1.44 T-5.61 C+2.86 m-3.94 \tau T-$

$$
-1.70 \tau \mathrm{Cm}-1.09 \mathrm{TCm} \text {. }
$$

The ANOVA (Table 6) confirms that the equation (3) adequately describes the adsorption removal of anthocyanins from the extracts of red cabbage by bentonite. Lack of fit associated elimination of few factors was 0.26. This was much lower compared with tabulated Fisher's $F$-value $=2.32$ for red cabbage extracts. It confirms that the obtained equation adequately describes adsorption removal of anthocyanins from the red cabbage extracts. It can be seen from Table 5 that for equation 3 , the value of the determination coefficient $\mathrm{R}^{2}$ was 0.9954 , while the values of adjusted determination coefficient $\mathrm{R}^{2}$ adj was 0.9914. It indicates a high degree of correlation between the experimental and predicted values.

The equation (3) shows the dependence of anthocyanin removal efficiency on individual factors as well as interactions between them and allows prediction of the removal of anthocyanins from red cabbage extracts by bentonite. Table 3 shows the removal efficiency of anthocyanins across the experimental and predicted values. The results indicate a good fit between the observed and predicted values.

Table 6. Analysis of variance for removal efficiency of anthocynians

\begin{tabular}{ccccccc}
\hline Term & DF & SS & MS & F & P-value & Comment \\
\hline$\tau$ & 2 & 1596.21 & 798.11 & 292.73 & 0.000 & $\mathrm{~S}=1.3431$ \\
$T$ & 2 & 99.19 & 49.59 & 260.18 & 0.000 & $\mathrm{R}^{2}=0.9954$ \\
$C$ & 2 & 1509.76 & 754.88 & 646.10 & 0.000 & $\mathrm{R}^{2}$ adj $=0.9914$ \\
$m$ & 2 & 393.31 & 196.65 & 159.60 & 0.000 & \\
$\tau \times T$ & 2 & 744.19 & 372.09 & 41.47 & 0.000 & \\
$\tau \times C \times m$ & 2 & 139.40 & 69.70 & 9.45 & 0.000 & \\
$T \times C \times m$ & 2 & 57.20 & 28.60 & 18.68 & 0.001 & \\
Residual error & 33 & 53.43 & 1.62 & & & \\
Lack of fit & 17 & 20.75 & 1.22 & 0.26 & & \\
Pure error & 16 & 74.18 & 4.64 & & & \\
Total & 47 & 4592.69 & & & &
\end{tabular}

\section{CONCLUSIONS}

In the present study, influence of the contact time (30-120 min), temperature (293-323 K), initial anthocyanin concentration (70-130 mg/L), and adsorbent mass $(10-25 \mathrm{~g} / \mathrm{L})$ ) on the removal efficiency of red cabbage anthocyanins was studied by using full factorial experimental design $2^{4}$. The analysis of variance indicated that all given above control factors and only some of their interactions (two-way interaction "contact time-temperature", three-way interactions "contact time-initial anthocyanin concentrationadsorbent mass" and "temperature-initial anthocyanin concentration-adsorbent mass") were significant at a $5 \%$ of probability level. According to our experimental results, the 
contact time has the more positive influence upon the removal of anthocyanins than the adsorbent mass. In its turn, the initial anthocyanin concentration has a more negative influence upon the removal efficiency of anthocyanins than the temperature. From the obtained results it follows that all significant interactions have a negative influence upon the removal efficiency of anthocyanins. We also obtained an adequate mathematical model for the removal efficiency of anthocyanins from red cabbage extracts with bentonite as the first-order polynomial equation which allows prediction of the anthocyanin removal.

\title{
Адсорбційне вилучення антоціанів з екстрактів червонокачанної капусти на бентоніті: статистичний аналіз основних ефектів та ефектів взаємодії
}

\author{
Л.М. Солдаткіна, В.О. Новотна \\ Одеський наиіональний університет імені I.I.Мечникова \\ вул. Дворянська, 2, Одеса, 65082, Україна, soldatkina@опи.еdи.иа
}

\begin{abstract}
Дослідження базується на повному факторному експерименті типу $2^{4}$, який використовувався для оцінювання внеску основних ефектів чотирьох факторів (час контакту, температура, початкова конщентрація антоціанів і маса адсорбента) та їхніх взаємодій на ефективність вилучення антоціанів з екстрактів червонокачанної капусти на бентоніті. Фактори досліджувались на двох рівнях $(-1 i+1)$. Встановлено, що час контакту та маса адсорбента мають позитивний ефект, а початкова концентрація антоціанів $і$ температура, а також взаємодія двох факторів «час контактутемпература», взаємодії трьох факторів «час контакту-початкова концентрачія антоціанів-маса адсорбента» $i$ «температура-вихідна кониентрація антоиіанів-маса адсорбента» негативно впливають на вилучення антоціанів з екстрактів червонокачанної капусти. В роботі запропонована математична модель адсорбиійного процесу з урахуванням головних ефектів факторів та їх взасмодій. Аналіз дисперсії та статистичні дані підтвердили ї̈ адекватність. Отримана модель дозволяс передбачити вилучення анточіанів із екстрактів червонокачанної капусти на бентоніті.
\end{abstract}

Ключові слова: адсорбиія, антоціани, червонокачанна капуста, бентоніт, статистичний аналіз, основні ефекти, ефекти взаємодї

\section{Адсорбционное выделение антоцианов из экстрактов краснокочанной капусты на бентоните: статистический анализ основных эффектов и эффектов взаимодействия}

\section{Л.М. Солдаткина, В.А. Новотная}

Одесский национальный университет имени И.И.Мечникова ул. Дворянская, 2, Одесса, 65082, Украина, soldatkina@onu.edu.иа

Исследование выполнено с помощью полного факторного эксперимента типа $2^{4}$, который позволил оценить вклад основных эффектов четырех факторов (время контакта, температура, начальная конщентрачия антоцианов и масса адсорбента) и их взаимодействия на эффрективность выделения антоцианов из экстрактов краснокочанной капусты на бентоните. Факторы изучались на двух уровнях $(-1 \quad u+1)$. Установлено, что время контакта и масса адсорбента имеют положительньй эффект, а начальная концентрация антоцианов и температура, а также взаимодействие двух факторов «время контакта-температура» и взаимодействия трех факторов «время контактаначальная концентрачия антоцианов-масса адсорбента» $и$ «температура-исходная концентрация антоцианов-масса адсорбента» отрицательно влияют на выделение антоцианов из экстрактов 
краснокочанной капусты на бентоните. В работе предложена математическая модель процесса адсорбции с учетом главных эффектов факторов и их взаимодействий. Анализ дисперсии и статистические данные подтвердили ее адекватность. Полученная модель позволяет предсказать выделение антоцианов из экстрактов краснокочанной капусты на бентоните.

Ключевые слова: адсорбиия, антоцианы, краснокочанная капуста, бентонит, статистический анализ, основные эффекты, эффекты взаимодействия

\section{REFERENCES}

1. Delgado-Vargas F., Paredes-Lopez O. Natural colorants for food and nutraceutical uses. (Boca Raton, London, New York, Washington, DC: CRC Press LLC, 2003).

2. Castañeda-Ovando A., Pacheco-Hernández M., Páez-Hernández M.E., Rodríguez J.A., Galán-Vidal C.A. Chemical studies of anthocyanins: A review. Food Chem. 2009. 113(4): 859.

3. Jampani C., Naik A., Raghavarao K.S.M.S. Purification of anthocyanins from jamun (Syzygium cumini L.) employing adsorption. Sep. Purif. Technol. 2014. 125: 170.

4. Lopes T.J., Quadri M.G.N., Quadri M.B. Recovery of anthocyanins from red cabbage using sandy porous medium enriched with clay. Appl. Clay. Sci. 2007. 37(1-2): 97.

5. Buran T.J., Sandhu A.K., Li Z., Rock C.R., Yang W.W., Gu L. Adsorption/desorption characteristics and separation of anthocyanins and polyphenols from blueberries using macroporous adsorbent resins. $J$. Food. Eng. 2014. 128: 167.

6. Coutinho M.R., Quadri M.B., Moreira R.F.P.M., Quadri M.G.N. Partial purification of anthocyanins from Brassica oleracea (red cabbage). Sep. Sci. Technol. 2004. 39(16): 3769.

7. Zhao Z., Wu M., Jiang Q., Zhao Z., Zhang Y., Chang X., Zhan K. Adsorption and desorption studies of anthocyanins from black peanut skins on macroporous resins. Int. J. Food. Eng. 2015. 11(6): 841.

8. Furuta S., Nishiba Y., Suda I. Fluorometric assay for screening antioxidative activity of vegetables. $J$. Food. Sci. 1997. 62(3): 526.

9. Dyrby M., Westergaard N., Stapelfeldt H. Light and heat sensitivity of red cabbage extract in soft drink model system. Food Chem. 2001. 72(4): 431.

10. Alghamdi E. The Intake of Red Cabbage Anthocyanines in Ice-cream. Life Sci. 2013. 10(1): 1885.

11. Patent EP 3187551 A1. Shida M., Ohara T., Fukino N., Kakizaki T., Ohno T., Hamasaki K., Yokoyama T., Imai M. Anthocyanin-based pigment composition. 2014.

12. Gimsing A.L., Sorensen J.Ch., Strobel B.W., Hansen H.Ch.B. Adsorption of glucosinolates to metal oxides, clay minerals and humic acid. Appl. Clay Sci. 2007. 35(3-4): 212.

13. Lee J., Durst R.W., Wrolstad R.E. Determination of total monomeric anthocyanin pigment content of fruit juices, beverages, natural colorants, and wines by the $\mathrm{pH}$ differential method: Collaborative study. $J$. AOAC Int. 2005. 88(5): 1269.

14. Rakitskaya T.L, Truba A.S, Kiose T.O., Berezina L.V., Davtyan A.S. Protolytic properties of natural and modified sorbents. Visn. Odes. Nac. Univ., Him. 2012. 17(2): 12. [in Ukrainian].

15. Antony J., Antony F.J. Teaching advanced statistical techniques to industrial engineers and business managers. J. Eng. Design. 1998. 9(1): 89.

16. Antony J., Roy R.K. Improving the process quality using statistical design of experiments: A case study. Qual. Assur. 1999. 6(2): 87.

17. Çoruh S., Gürkan H.E. Adsorption of neutral red from aqueous solutions using waste foundry sand: full factorial design analysis. Environ. Prog. Sustain. Energ. 2014. 33(4): 1086.

18. Safa Y., Bhatti H.N. Adsorptive removal of direct textile dyes by low cost agricultural waste: application of factorial design analysis. Chem. Eng. J. 2011. 167(1): 35.

19. Mathialagan T., Viraraghavan T. Biosorption of pentachlorophenol by fungal biomass from aqueous solutions: a factorial design analysis. Environ. Technol. 2005. 26(5): 571. 